\title{
Indoor Air Pollution in Non Ac Passenger Bus
}

\author{
Iksiroh El Husna ${ }^{1,2^{*}}$, Yan El Rizal Unzilatirrizqi $\mathrm{D}^{3}$, Yudi Karyanto ${ }^{3}$, and Henna R Sunoko ${ }^{1,4}$ \\ ${ }^{1}$ Doctoral Program of Environmental Science, School of Postgraduate Studies, Diponegoro University, Semarang-Indonesia \\ ${ }^{2}$ Nautical Departement, Merchant Marine Polytechnic Semarang, Jingosari 2A, Semarang, Indonesia \\ ${ }^{3}$ Automotive Engineering, Polytecnic of Road Safety Transport, Jl. Semeru No. 3, 50125,Tegal, Indonesia \\ ${ }^{4}$ Faculty of Medic ine, Diponegoro University, Jl. Prof Sudharto SH, 5027, Semarang, Indonesia
}

\begin{abstract}
Passenger buses have been one of favorite means of transportation in Indonesia due to its affordability and flexibility. Intensity of human activities during the trip in the buses have a potential of causing indoor air pollution (polusi udara dalam ruang; PUDR). The indoor air pollution has an impact of 1000-time bigger than outdoor air pollution (polusi udara luar ruang; PULR) on lung. This study aimed to find out indoor air pollution rate of non air conditioned buses using an approach to biological agent pollutant source. The study applied an analysis restricted to microorganisms persistence as one of the sources of the indoor air pollution. The media were placed in different parts of the non AC buses. This study revealed that fungs were found in the non AC buses. They became contaminants and developed pathogenic bacteria that caused air pollution.
\end{abstract}

\section{Introduction}

Passenger buses have been one of favorite means of transportation in Indonesia due to its affordability and flexibility. Buses are capable of transporting large number of passengers and ranging varied distances during the trip. However, few studies have been undergone concerning bus-borne indoor air pollution. [1] Indoor air pollution is derived from many sources, including building materials, biological agent, and even humans who occupy the room. Pollution cause by externalities brought in the room may take the forms of soil-borne gases. These pollution sources are derived from burning, evaporation, biological agent, and radon. Burned materials come from gasoline and wooden stoves, cigarettes, chimneys, as well as room heater. Biological agents can be produced by organisms in domesticated animals and human. [2] Such criteria are relevant to the incidence of the indoor air pollution in the buses that transport humans.

\subsection{Indoor Air Pollution}

Indoor air quality in a particular room is a scientific aspect that focuses on the air quality in particular room, which is to be transferred to the room or building occupied by humans. Indoor air quality can be defined as a result of interaction between place, temperature, building system, construction technique, contaminant source, building equipment, humidity, process, and activity within the room as well as other sources of externalities and workers. [3].

Studies in the United States and Europe proved that individuals spent most times indoor; children, patients and urban dwellers even stay longer indoor, spending
$90 \%$ of the total daily activities. [4] Indoor air pollution does not only occur in factories and urban settlements, but also in rural areas, which produce burning materials from wood, charcoal, husk, and gasoline stove. In developing countries, more than a million population burn wood and other biomass fuels without installing adequate chimneys in their houses. [5]

There have been several studies on the indoor air pollution, such as that in India, concerning water quality inside the buses using $\mathrm{CO} 2$ parameter. [1] Another study in 2015 was performed to find out the indoor air quality using a biological parameter approach, but in other locus than bus. The study revealed that indoor air pollution rate was beyond the quality thresholds, resulting in 508 $\mathrm{CFU} / \mathrm{m} 3$ germs. The result suggested the need for a special effort in preventing the indoor air pollution, while maintaining human health. [3]

\subsection{Biological agent}

Heating process, ventilation, and air conditioner (AC) affect indoor humidity and air quality. Vapor accumulation in a building construction causes humidity and microbial growth. Symptoms for such phenomenon ranges from change in color, material surface leakage, wet spots, and attachment, and fungal odor. Sources of humidity are rain water, surface water, groundwater, and local water with poor drainage systems, which are condensated. [4] Bacteria and fungi can also be found in foods. They grow abundantly in water tract, air conditioner, moisturizer, air cleaning filter, carpet and poor ventilated room in the basement. Viruses and germs are transported into the room by human, domesticated

* Corresponding author: iksirmahfudz@,yahoo.co.id 
animals or pets, and insects. Insects may grow abundantly in sofa, chair, carpet, and bedroom. [6]

Biological agents exposure are often correlated to non-specific symptoms of upper and lower respiratory tract disorders; some episodes may include sick building syndrome, a situation that causes acute symptoms, such as skin irritation, mucosal membrane, and other symptoms developed by workers/inhabitants of modern buildings. However, the syndrome does not identify specific diseases and the causes are unidentified. These complaints can occur locally in a specific room of the building, but may also spread over the building. [7]

\section{Research methodologies}

This study was performed to analyze air quality restricted to biological agent. The purpose was to find out the indoor air quality in the buses. The study applied a viable air sample method and used blood agar and nutrient agar media to grow microorganisms trapped within buses in Tegal, Central Java. The media were placed in different points of the buses justified as an intense rooms occupied by human. This method applied a growth medium of agar in petri dish or agar strips to grow the trapped microorganisms. The culture method had an advantage of detecting bacteria (in addition to spore), providing a broad illustration of the number of the microorganisms living in the air, and determining microorganism species because it comprised a single colony for further culture. In this study biological parameter used was germs and fungi persistence as an indicator for the indoor air pollution. The parameter was then compared to the quality threshold pursuant to the Decree of the Minister of Health Affairs of the Republic Indonesia 1204/Men Kes/SK/X/2004 on the Requirements for Environmental Health.

\section{Results and discussion}

This study was performed to find out the indoor air quality by focusing on microorganism indicators, i.e. germs and fungi. Results obtained were then compared to the quality threshold pursuant to the aforementioned Ministerial Decree on the Requirements for Environmental Health (indoor: $200 \mathrm{CFU} / \mathrm{m} 3$ ). The results found that such germs as Bacillus subtilis, Staphylococcus aureus, Staph epidermidis, Klebsiella sp., Streptococcus, and Escherechia coli, all being pathogenic germs, had caused indoor air pollution. In addition, the study also found some fungi species, i.e. Aspergillus fumigatus, Penicillum sp., mod, and Aspergillus niger as the contaminants that caused the air pollution and pathogenic germs, as well. Details of the results are presented in the following table.
Table 1. Germs Identification

\begin{tabular}{|c|c|c|c|}
\hline NO & Room & $\begin{array}{c}\text { Germ } \\
\text { Population } \\
\left(\mathbf{C F U} / \mathbf{M}^{3}\right) \\
\end{array}$ & Germs \\
\hline 1 & 1.1 & 17 & $\begin{array}{l}\text { Bacillus Subtilis, Staphylococus } \\
\text { aureus, staph epidermidis }\end{array}$ \\
\hline 2 & 1.2 & 24 & $\begin{array}{l}\text { Bacillus Subtilis, Staphylococus } \\
\text { aureus, staph epidermidis, } \\
\text { Klebsiella sp }\end{array}$ \\
\hline 3 & 4.1 & 22 & $\begin{array}{l}\text { Bacillus Subtilis, Staphylococus } \\
\text { aureus, staph epidermidis }\end{array}$ \\
\hline 4 & 4.2 & 49 & $\begin{array}{l}\text { Bacillus Subtilis, Staphylococus } \\
\text { aureus, staph epidermidis }\end{array}$ \\
\hline 5 & 5.1 & 52 & $\begin{array}{l}\text { Bacillus Subtilis, Staphylococus } \\
\text { aureus, staph epidermidis, } \\
\text { Streptococcus, and Escherichia } \\
\text { coli }\end{array}$ \\
\hline 6 & 5.2 & 38 & $\begin{array}{l}\text { Bacillus Subtilis, Staphylococus } \\
\text { aureus, staph epidermidis, } \\
\text { Streptococcus, and Escherichia } \\
\text { coli }\end{array}$ \\
\hline \multicolumn{2}{|c|}{$\begin{array}{l}\text { Max } \\
\text { Threshold }\end{array}$} & 200 & \\
\hline
\end{tabular}

Bacillus subtilis were found in the buses. They usually grew in soil and human digestive system. This block-shaped bacillus is capable of developing hard protecting endospora, which allows it to tolerate extreme environmental conditions. These bacteria take part into the enzymatic production secreted by industrial activities, such as biotechnological factories. Staphylococcus aureus bacteria are the most dangerous of all staphylococcus genus. These bacteria spread by having a direct contact with infected individuals, mediated by contaminated materials, or inhaling the infected drops dispersed by sneezing and cough. The Staphylococcus aureus may have access to all body organs, from outer skin to cardiac system, lung, bone and produce toxins. Staphylococcus epidermis is one of bacterial species from the genus of Staphylococcus, which potential causes opportunistic infection (infecting individuals with low immunity). These bacteria are found in human mouth and colon and are pathogenic in nature. The pathogenic Streptococcus may cause several diseases, such as pneumonia, meningitis, necrotizing fasciitis, erisipelas, throat inflammation, and endokarditis. [8]

Furthermore, the table also proved the persistence of Escherichia coli. These bacteria are usually found in human colon. Most of them are harmless, but some species, such as E. coli type O157:H7, produce toxins that contaminated human foods, causing blooded diarrhea due to exotoxin derived from verotoxin. Klebsiella cause pneumonia, urinary tract infection, septikemia, meningitis, diarrhea, and soft tissue infection. This species also contributes to pathogenesis 
of ankylosing spondylitis and other spondyloarthropaties. Most of Klebsiella infections in human are caused by Klebsiella pneumoniae and Klebsiella oxytoca. The Klebsiella infection often occurs to very young as well as very old individuals, indicating the development of cancer. This species usually contaminated invasive medical equipments. [8]

Table 2. Fungi Identification

\begin{tabular}{|c|c|c|c|}
\hline NO & Room & $\begin{array}{c}\text { Fungi } \\
\text { Population } \\
\left(\mathrm{CFU} / \mathbf{M}^{3}\right)\end{array}$ & Fungi \\
\hline 1 & 1.1 & 12 & $\begin{array}{l}\text { Aspergilus fumigatus, } \\
\text { Penicilium sp, Mold }\end{array}$ \\
\hline 2 & 1.2 & 9 & Aspergilus fumigatus \\
\hline 3 & 4.1 & 12 & $\begin{array}{l}\text { Aspergilus fumigatus, } \\
\text { Penicilium sp, Aspergilus Niger }\end{array}$ \\
\hline 4 & 4.2 & 3 & $\begin{array}{ll}\text { Aspergilus } & \text { fumigatus, } \\
\text { Penicilium } s p & \\
\end{array}$ \\
\hline 5 & 5.1 & 6 & $\begin{array}{l}\text { Aspergilus } \\
\text { Aspergilus Niger }\end{array}$ \\
\hline 6 & 5.2 & 2 & Aspergilus Niger \\
\hline $\begin{array}{l}\text { Max } \\
\text { Thre }\end{array}$ & & 0 & \\
\hline
\end{tabular}

Infections due to Aspergillus cause significant morbidity and mortality. Most of the infections are correlated to Aspergillus fumigatus, Aspergillus flavus and Aspergillus terreus. Whereas, Aspergillus niger was rarely reported as the cause of invasive diseases, more likely related to automikosis [9], cutaneous infection [10], penumonia, fatal lung infection, and long-term steroid for COPD (chronic obstructive pulmonary disease). [11] An examination of the COPD patients with invasive lung aspergillosis revealed that $3.6 \%$ of the total cases were caused by Aspergillus niger. [2] Other case indicated that Aspergillus niger related to $75 \%$ of the mortality rates in the infected patients. [12] The mold may grow indoor and outdoor and they are found in abundance in warm and humid environment. Whereas, Penicillium species usually found indoor was Penicillium chrysogenum. This species produces toxins with a moderate toxicity and causes allergy and infection, in particular in the patients without immediate intervention and medication.

\section{Conclusions}

The study on the non AC buses using the biological agent parameter as the indicator for the indoor air pollution revealed that the non $\mathrm{AC}$ buses contained bacteria, i.e. Bacillus subtilis, Staphylococcus aureus, Staph epidermis, Klebsiella sp., Streptocossus, and Eschericia coli. The rate was still considered below the maximum threshold. However, they produced pathogenic germs harmful for human health. The study also found fungi, i.e. Aspergilus fumigatus, Penicillium sp., mold, and Aspergillus niger, all pathogenic and harmful for human health.

\section{References}

1. A. Gajewski, Indoor air quality in a bus. Safety and Security Engineering $V 749$ Department of Heat Engineering, Faculty of Civil Engineering and Environmental Engineering, Bialystok University of Technology, Poland, (2016)

2. JR. Balmes, IB. Tager, MD. Eisner, Air pollutant. In: JR. Manson, JF. Murray, VC. Broaddus, JA. Nadel, eds. 4th ed. Philadelphia:Elsevier Saunders, pp.1800$14,(2005)$

3. WHO. Indoor air pollutan and household energy. [cited 2005 Des 2006]. Available from: http://www.who.int/heli/risks/indoor.air/en/index.htm 1

4. U.S Enviromental protection agency. Indoor air pullutan: An introduction for health professionals. [cited 2005 Des 4]. Available from: http://www.cpsc.gov/cpscpub/455. Html

5. L. Fianchi, M. Picardi, L. Cudillo, L. Corvatta, L. Mele, G. Trape, C. Girmenia, and L. Pagano. Mycoses 47, 163-167. [PubMed], (2004).

6. J. Wiggins, T. J. Clark, and B. Corrin, Thorax 44, 440-441. [PMC free article] [PubMed], (1989).

7. K. W. Loudon, A. P. Coke, J. P. Burnie, A. J. Shaw, B. A. Oppenheim, and C. Q. Morris, J Hosp Infect 32, 191-198. [PubMed], (1996).

8. P. Bulpa, A. Dive, and Y. Sibille, Eur Respir J 30, 782-800. [PubMed], (2007).

9. KJ. Ryan; CG. Ray (editors). Sherris Medical Microbiology (4th ed. ed.). McGraw Hill. ISBN 08385-8529-9 (2004)

10. Husna, Iksiroh El \& Yan El Rizal. Analisis Mikroorganisme Untuk Mengetahui Tingkat Pencemaran Udara Dalam Ruang di Gedung PKB PKTJ Tegal (National Conference On Conservation For Better Life 2014

11. JM. Samet, MJ. Utell, Pulmonary Diseases and Disorders. New York: McGraw-Hill Co, pp. 941-62, (1998) 